\title{
SANTO DE CASA NÃO FAZ MILAGRE: OS SENTIDOS DA DEVOÇÃO NA PARÓQuia de São JudAs TADEU do baIRRo do Jabaquara, SP.
}

\section{Bianca Arruda}

O livro de Rodolfo Guttilla, A casa do santo $\mathcal{E}$ o santo de casa, oferece uma valiosa descrição do universo de devoção a São Judas Tadeu no santuário do bairro do Jabaquara, na cidade de São Paulo. A partir desta temática, privilegia, sobretudo, os meandros das disputas institucionais ocorridas ao longo da história dessa paróquia, num contexto em que a devoção "autorizada" nem sempre corresponde à devoção praticada pelos fiéis e devotos dos santos católicos.

A referida análise se insere no conjunto de estudos desenvolvidos durante os anos de 1988, 1992 e 2005, na paróquia de São Judas Tadeu, pelo Instituto de Estudos da Religião (ISER), junto ao qual Guttilla trabalhou como pesquisador convidado. Por ter sido encomendada pelos próprios paroquianos, a análise realizada pelo ISER teve por finalidade "servir de ponto de partida para [a] atuação pastoral junto aos devotos" (:159), sendo que, como nos elucida o antropólogo, essa "atuação pastoral" é reflexo de um processo de disputas no interior dessa mesma paróquia, a qual tem passado por significativas mudanças nas suas orientações de culto e organização, ora consolidando a perspectiva do catolicismo renovado, que tende a desvalorizar as manifestações de devoção "popular", ora adotando medidas reformadoras, que têm maior aceitação entre os fiéis e são mais permissivas com as práticas votivas da população.

Nesse sentido, a análise contida na obra de Guttilla se particulariza por ilustrar como os direcionamentos "universalizantes" do Vaticano são recebidos e administrados nas paróquias que, inseridas num universo de contendas ocultas aos olhos da Igreja Católica, trabalham de modo a adequar às suas experiências locais as diretrizes gerais e, conseqüentemente, transformam as mesmas. Percebemos, então, que esse trabalho contribui para iluminar nosso entendimento sobre as relações existentes entre fiéis, agentes institucionais e diretrizes organizacionais da Igreja Católica, colaborando para ampliar a compreensão a respeito da dinâmica das devoções populares e sua importância para a Igreja.

Guttilla apóia-se na noção bourdiana de que a religião é "um sistema simbólico a um só tempo estruturado e estruturante, que constrói e expressa a 
realidade, estabelecendo o sentido imediato do mundo e, em particular, do mundo social" (:26). Dessa maneira, diferentes grupos e classes sociais disputam, no campo religioso, as formas pelas quais podem impor a definição de mundo social mais de acordo com seus interesses.

Assim, para o autor, as "cosmovisões" antagônicas em questão no caso da devoção no bairro do Jabaquara expressam, de um lado, a perspectiva da "casa do santo", segundo a qual os padres e agentes leigos envolvidos com o projeto de evangelização da comunidade são socialmente reconhecidos como os mais capacitados a produzir e difundir a devoção; e, de outro, a dos devotos que cultuam o "santo de casa", constituindo "um grupo social que acredita mais nas relações pessoais, na instituição familiar, e nos valores tradicionais (...) do que na ética individualista da sociedade contemporânea, particularmente forte nas grandes cidades" (:188). Ou seja, expondo de modo claro e conciso, a tese de Guttilla sobre a devoção a São Judas Tadeu consiste (apenas) num caso exemplar do que acontece na "religiosidade brasileira": a devoção a esse santo evidencia o "clima de intimidade e familiaridade" (:21) característico da relação dos brasileiros com seus protetores que permanece ativo num contexto de urbanização, ainda que posto em contato com outros tipos de relação.

Pensar sobre "a casa do santo", desse modo, permite a Guttilla empreender uma reflexão sobre a devoção num espaço institucional, regrado, público e controlado por agentes religiosos que nem sempre seguem as mesmas diretrizes. Já o "santo de casa" compõe, como vimos, o quadro de referências dessa devoção familiar, pessoal, privada, na qual as regras são voláteis e reelaboradas na relação entre o devoto e o santo.

Assim, no capítulo primeiro, o autor faz uma retrospectiva dos estudos sobre os cultos aos santos no Brasil, apoiando-se sobremaneira nas concepções que postulam ser esse tipo de devoção uma reminiscência dos tempos coloniais em que a sociedade patriarcal tinha a necessidade de justificar e traduzir a desigualdade social para a população.

Em seguida, Guttilla elucida a origem da devoção a São Judas Tadeu no bairro do Jabaquara num contexto de "romanização" do catolicismo brasileiro, e destaca a importância de agentes sociais e contingências históricas que tiveram papel decisivo na disseminação do culto neste bairro e, posteriormente, na cidade de São Paulo. Como explica o autor, a devoção a São Judas Tadeu é um fenômeno recente e localizado que se confunde com a criação da paróquia que leva o nome do santo, tendo como principal articulista o seu fundador e primeiro vigário, o padre João Buscher, da Congregação do Sagrado Coração de Jesus, responsável por difundir os atributos, a hagiografia e a iconografia do patrono "nos casos desesperados, nos negócios sem remédios". Para Guttilla, é "a partir desse núcleo original, [que] a devoção se irradiará para centenas de outras cidades no país, seja por meio de programas de rádio dedicados à sua devoção, 
seja pela criação de igrejas consagradas ao santo, especialmente em grandes centros urbanos, como Rio de Janeiro, Salvador e Belo Horizonte" (:21).

No terceiro capítulo, o antropólogo esclarece as distinções na orientação do catolicismo renovado e do catolicismo reformador decorrentes das diretrizes estabelecidas no Concílio do Vaticano II e suas implicações para a devoção no santuário do Jabaquara, afirmando que "o que está em jogo no período são as relações de hierarquia e poder na condução da vida religiosa" (:116). Por fim, nos capítulos quarto e quinto, ele dedica-se a descrever as reações dos padres e devotos às novas orientações do Vaticano II, enfocando o movimento de "privatização" da devoção operado pelos fiéis e as características desse processo.

É importante comentar que o estudo de Guttilla consiste num esforço de analisar manifestações do catolicismo popular em contextos urbanos, observando que, em geral, as análises das ciências sociais privilegiam ou aspectos da implantação do catolicismo no país, ou o conjunto das reformas ocorridas na Igreja na segunda metade do século XIX, ou, ainda, as características das práticas do catolicismo popular em espaços não urbanizados, operando de modo a dissociar "religião" de "sociedade". Essa constatação leva-o a afirmar que seu estudo busca recuperar "(...) o arcabouço social da devoção, suas estruturas de significação e a sua própria razão de ser e existir em um mundo, como querem alguns, 'desencantado'” (:25).

Todavia, consideramos que a insistência do autor em buscar uma explicação para a existência da devoção em um mundo "desencantado" leva-o a reproduzir uma tendência que assombra os estudos antropológicos sobre o catolicismo popular: a insistência na "nostalgia camponesa" (Montero 1999:336) que, traduzida num continuum folk-urbano, valida suas explicações. Isto é, para entender as manifestações de devoção "populares" numa grande cidade, Guttilla não hesita em afirmar que o culto aos santos no Brasil tem origem na época colonial, período em que esta prática possuía a função social de oferecer não só instrumentos para um maior domínio simbólico sobre a natureza como também servia para tornar aceitável a "lógica do sistema de relações sociais na formação da sociedade patriarcal, dominada pelo familismo e pela patronagem" (:53). Para ele, esta lógica permanece viva ainda hoje na "cosmovisão" das camadas populares.

Além disso, compreendemos que essa perspectiva corre o risco de reduzir as cosmologias e classificações nativas a resultados de um processo de disputas no plano político e social em que os nativos "dominados" (ou melhor, os devotos), submetem seus valores e sua cultura às interpretações dos "dominantes" (os agentes eclesiais autorizados a lidar com o sagrado). Dessa forma, as adequações às classificações impostas são interpretadas como a busca de "capital simbólico" numa luta por status entre os paroquianos de São Judas Tadeu, do Jabaquara. Mas, se levarmos em conta que as pessoas não agem apenas com o objetivo de capitalizar poder e, também, se considerarmos que a fé e as filiações às religiões 
podem ser compreendidas não somente pelas contendas entre mercados religiosos, tal análise deixa de exercer a atração inicial, pois oferece-nos a descrição de apenas uma parte do vasto universo de relações entre os homens e seus deuses.

Portanto, apesar de considerarmos que o estudo de Guttilla nos oferece uma rica descrição do fenômeno de devoção a São Judas Tadeu, ponderamos que sua ênfase na busca de uma explicação para as diferentes formas de manifestações de devoção, e o privilégio da análise dos materiais institucionais (boletins, atas, documentos históricos e outros discursos "autorizados") sobre o assunto, contribuem para o pouco espaço deixado no livro à descrição das práticas e das narrativas dos devotos sobre suas experiências. Estas aparecem apenas como exemplos de reação à ação institucional, ou como ilustrações das manifestações do chamado catolicismo popular.

Finalmente, gostaríamos de elogiar o projeto gráfico e a editoração do livro de Guttilla: a generosidade e a qualidade das fotos compõem um referencial imprescindível e enriquecedor para compreendermos ainda melhor as manifestações de devoção no santuário do Jabaquara.

\section{Referências Bibliográficas}

MONTERO, Paula. (1999), "Religiões e dilemas da sociedade brasileira". In: S. Miceli. O que ler na ciência social brasileira (1970-1995) - Antropologia. São Paulo: Editora Sumaré.

Bianca Arruda (biartistic@gmail.com.br) Mestranda em Antropologia Social pelo PPGAS / MN / UFRJ. 